\title{
Renal Phenotype of ET-1 Transgenic Mice is Modulated by ANDROGENS
}

\author{
P. Kalk ${ }^{1,2 *}$, C. Thöne-Reineke ${ }^{1 *}$, A. Schwarz ${ }^{1}$, M. Godes ${ }^{1,2}$, C. Bauer ${ }^{3}$, T. Pfab ${ }^{2}$, B. Hocher ${ }^{1}$ \\ ${ }^{1}$ Center for Cardiovascular Research/Department of Pharmacology and Toxicology, Charite, Berlin, Germany \\ ${ }^{2}$ Department of Nephrology, Charite-Campus Benjamin Franklin, Berlin, Germany \\ ${ }^{3}$ Institute of Biochemistry and Molecular Biology, Free University, Berlin, Germany
}

\begin{abstract}
Introduction: Activation of the endothelin (ET) system promotes inflammation and fibrosis in various tissues including the kidney. Male ET-1 transgenic mice are characterized by chronic kidney inflammation and renal scarring. We hypothesized that this renal phenotype might be modulated by androgens. Thus the aim of our study was to elucidate the impact of gonadectomy in ET-1 transgenic mice on kidney function and morphology.

Methods: Male ET-1 transgenic mice at the age of 10 weeks were randomly allocated to the following groups: normal ET transgenic mice $(\mathrm{ET} ; \mathrm{n}=17)$ and ET transgenic mice that underwent castration $(\mathrm{ET}+\mathrm{cas} ; \mathrm{n}=12)$. Study duration was 9 months. Creatinine clearance and protein excretion was monitored. At study end animals were sacrificed and kidneys were harvested for histology/immunhistochemistry.

Results: Castration significantly ameliorated glomerulosclerosis in ET-1 transgenic mice (ET glomerulosclerosis-score: $3.0 \pm 0.17$ vs ET+cas: $2.4 \pm 0.17$; $\mathrm{p}<0.05$ ) as well as renal perivascular fibrosis (ET fibrosis-score: $3.0 \pm 0.14$ vs ET+cas: $2.2 \pm 0.14 ; \mathrm{p}<$ 0.05). However, interstitial fibrosis and media/lumenratio of renal arteries remained unaffected by castration. Regarding inflammation, castration significantly reduced the number of CD4-positive cells in renal tissue of ET-1 transgenic mice (ET CD4-positive cells/10000 cells: $355 \pm 72$ vs ET+cas: $147 \pm 28$; $<<$ 0.05). Renal tissue contents of CD8 positive cells as well as of macrophages were not affected by castration. Regarding kidney function castration significantly reduced proteinuria in ET-1 transgenic mice whereas creatinine clearance did not differ between study groups.

Conclusion: Our study demonstrates that the renal histopathological phenotype in male ET-1 transgenic mice with regard to glomerulosclerosis, proteinuria, perivascular fibrosis and immune cell immigration is ameliorated by castration. We thus conclude that the effects of ET-1 overexpression on renal tissue injury are modulated by androgens.
\end{abstract}

Key words: ET-1, castration, renal phenotype

*Both authors contributed equally to the paper.

\section{INTRODUCTION}

Endothelin (ET-1) exhibits potent pro-inflammatory and pro-fibrotic properties. Thus, ET-1 transgenic mice overexpressing human ET-1 are characterized by inflammation and fibrosis in various tissues including the kidney (Hocher et al. 1997; Hocher et al. 2000b). However, those studies were carried out using male animals only, therefore the impact of sex hormones on the ET-1-induced phenotype in this model remains unknown. Gender-related differences play a vital role in human cardiovascular disease (for review, see (Regitz-Zagrosek 2006)). Also, gender-related differences in the regulation of vascular tone by ET-1 are described in both human (Ergul et al. 1998) and animal studies (Tatchum-Talom et al. 2000). However, most research in this field focuses on the role of female sex hormones, literature on the impact of androgens on ET-1-induced phenotype is limited.

Thus, our study aimed at elucidating the impact of androgens on the renal phenotype of ET-1 transgenic mice in animals with and without gonadectomy.

\section{MATERials AND MeHTOds}

\section{Study Design}

Animal studies were carried out in accordance with German law governing the use and care of laboratory animals. For our study only male human-ET-1 transgenic mice were used. Animals were housed under standardized conditions with water and food ad libitum. At the age of 10 weeks the animals were randomly allocated to 2 study groups: normal ET transgenic mice (ET; $\mathrm{n}=17)$ and ET transgenic mice that underwent castration (ET+CAS; $\mathrm{n}=12)$.

Castration was performed in general anaesthesia using Xylazine/Ketamin ip at a dose of $12 \mathrm{mg} / 80 \mathrm{mg}$ per $\mathrm{kg} / \mathrm{BW}$. Afterwards, anaesthetized mice were put on a heated table to maintain normal body temperature and scrotum was incised, testicles ligated and removed. Then scrotum was closed with sutures.

After 6 months animals were put in metabolic cages for $24 \mathrm{~h}$ in order to obtain urine samples and blood samples were taken thereafter for calculation of creatinine clearance using standard formula. 
Study duration was 9 months; afterwards animals were sacrificed and kidneys were harvested for histology/immunohistology studies.

\section{Histological STUdies}

Renal tissue samples were all embedded in paraffin, cut into $3 \mu \mathrm{m}$ sections, subjected to Sirius Red-, periodic acid Schiff- (PAS) and hematoxylin-eosin (HE) staining. Quantitative stereology (i.e. intima/media and lumen area of renal arteries) was analyzed using a computer-aided image analysis system as previously described (Hocher et al. 1999). Renal morphology (interstitial fibrosis, perivascular fibrosis and glomerulosclerosis) was measured as recently described (Hocher et al. 2000a; Haffner et al. 2005). In brief, interstitial fibrosis was evaluated after Sirius Red (SR) staining using computer-aided histomorphometry devices. We measured the relationship of SR- stained area (connective tissue) to total area of the whole section using a light microscope combined with a digital camera. The data thus obtained were analyzed using a PowerMAC and image processing software (Image 1.61 program, shareware of the NIH).

For calculation of the media/lumen ratio of renal arteries we measured the area contents of the media and the lumen after HE-staining using the Image 1.61 program.

Perivascular fibrosis was graded in Sirius Red staining via a scoring system by two independent investigators using who were blinded to the study groups of the animals. Likewise glomerulosclerosis was quantified in PAS.

\section{IMMUNOHISTOCHEMISTRY}

Slides with 3-mm-thick paraffin sections were dewaxed in xylol (twice for $5 \mathrm{~min}$ ), and rehydrated in $100 \%$ ethanol (twice for $5 \mathrm{~min}$ ), $75 \%$ ethanol ( $5 \mathrm{~min}$ ), and tap water $(5 \mathrm{~min})$. After washing in Tris-buffered saline (TBS) (twice for $3 \mathrm{~min}$ ), paraffin sections were digested with $0.0025 \%$ trypsin in $0.1 \%$ calcium chloride, $\mathrm{pH} 7.8$, for $15 \mathrm{~min}$ at $37^{\circ} \mathrm{C}$, followed by washing in TBS buffer, pH 7.5 (5 min). The sections were denaturated with $4 \mathrm{~mol} /$ liter $\mathrm{HCl}$ for $15 \mathrm{~min}$. Nonspecific binding sites were blocked with incubation buffer (bovine serum albumin [BSA], Triton X100, and phosphate-buffered saline [PBS]; three times for $5 \mathrm{~min}$ ) at room temperature. Excess buffer was removed and the sections were circled with a waterproof pen (Dako, Glostrup, Denmark) and incubated with primary monoclonal antibody (rat anti-mouse mature macrophage antibodies (Austyn \& Gordon 1981), anti-CD4 antibodies, anti-CD 8 antibodies) for $2 \mathrm{~h}$ at $37^{\circ} \mathrm{C}$, then overnight at $4^{\circ} \mathrm{C}$. Negative control slides were incubated with incubation buffer alone. After washing in PBS the slides were incubated with biotinylated rabbit antirat immunoglobulin G (Jackson ImmunoResearch Labs, West Baltimore, MD), followed by alkalinephosphatase-conjugated streptavidin complex (Jackson ImmunoResearch) and Fast Red Tablets (Boehringer-Mannheim, Germany) according to the user's manual. Afterwards, sections were analyzed by light microscopy and by a computer-aided image analysis system. We measured the relation of redstained cells (positive cells) to total cell number of the whole kidney section using the above described computer- aided image analysis system.

\section{STATISTICAL ANALYSis}

The data are expressed as means \pm SEM. Data for the groups were compared using unpaired student's t-test and ANOVA. Statistical significance was assumed with a value of $\mathrm{p}<0.05$.

\section{RESULTS}

Renal function was assessed using metabolic cage experiments at the age of 6 months. Whereas castration had no impact of GFR in ET-1 transgenic mice, protein excretion was significantly attenuated in castrated ET-1 transgenic mice versus normal male ET-1 transgenic mice (see Table 1).

Table 1. Synopsis of GFR, renal histology and immunohistochemistry.

\begin{tabular}{ccc}
\hline Parameter & ET & ET+CAS \\
\hline GFR (ml/min) & $0.29 \pm 0.05$ & $0.37 \pm 0.02$ \\
Protein Excretion (mg/24h) & $30 \pm 2.6$ & $5+/ 0.4^{*}$ \\
Interstitial Fibrosis (\%) & $17.8 \pm 1.9$ & $14.6 \pm 1.8$ \\
Media/Lumen-Ratio & $2.0 \pm 0.3$ & $2.0 \pm 0.3$ \\
CD8+cells/10000 cells & $1987 \pm 329$ & $2352 \pm 397$ \\
Macrophages/10000 cells & $3552 \pm 396$ & $3446 \pm 26$ \\
\hline
\end{tabular}

All values are given as means \pm SEM. $*: \mathrm{p}<0.05$ vs. ET

Renal morphology was assessed at study end. Castration had no impact on renal interstitial fibrosis or media/lumen-ratio of renal arteries (see Table 1). However, both glomerulosclerosis and perivascular fibrosis were significantly attenuated in castrated ET-1 transgenic mice (see Fig. 1A+B). Immunohistochemistry revealed significantly reduced renal CD4+ cell contents in castrated ET-1 transgenic mice versus uncastrated controls (see Fig. 1C), whereas no difference concerning renal CD8+ cells or macrophage numbers was detected between the study groups.

\section{DISCUSSION}

Our study demonstrates that the renal histopathological phenotype in male ET-1 transgenic mice with regard to glomerulosclerosis, proteinuria, perivascular fibrosis and immune cell immigration is ameliorated by castration. The onset of renal glomerulosclerosis, inflammation and fibrosis is consistent with the literature describing the renal phenotype of ET-1 transgenic mice (Hocher et al. 1997). The fact that all detrimental changes associated with ET-1 overexpression are attenuated by gonadectomy suggests a specific interaction of male sex hormones with the endothelin system. This is in line with a human study (Polderman et al. 1993) describing plasma ET-1 levels in male, fe- 
Glomerulosclerosis

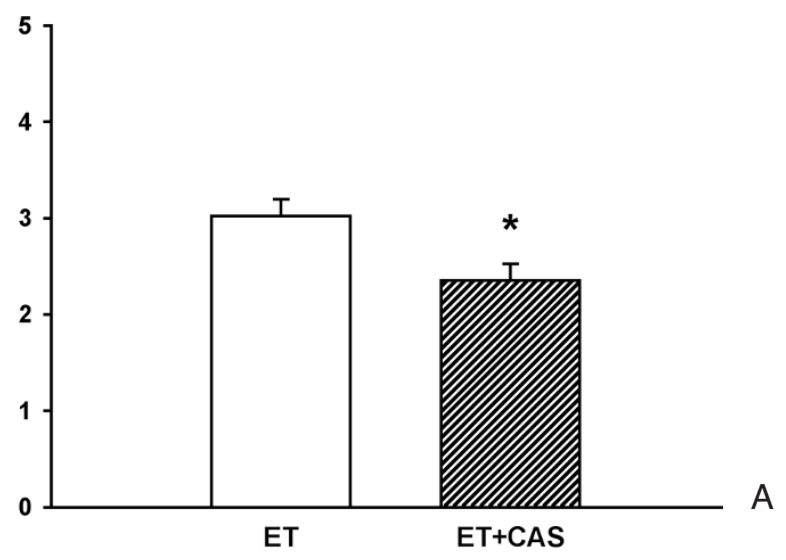

Renal Perivascular Fibrosis

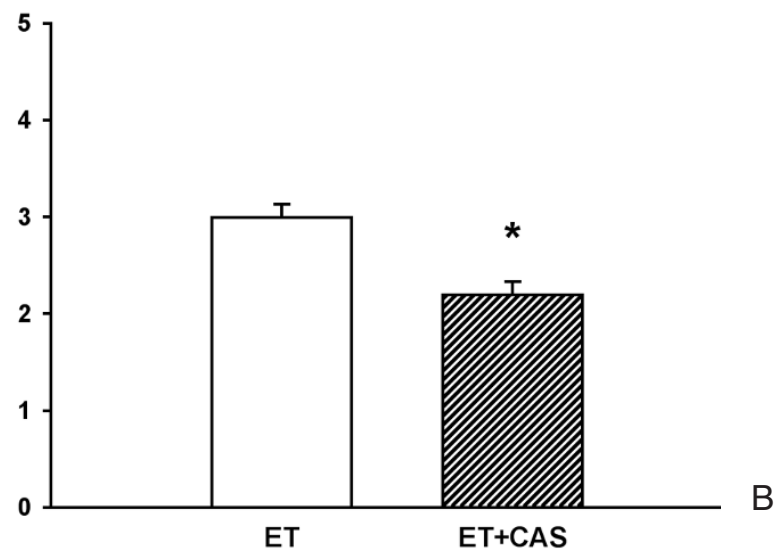

Renal CD4+ Cell Content

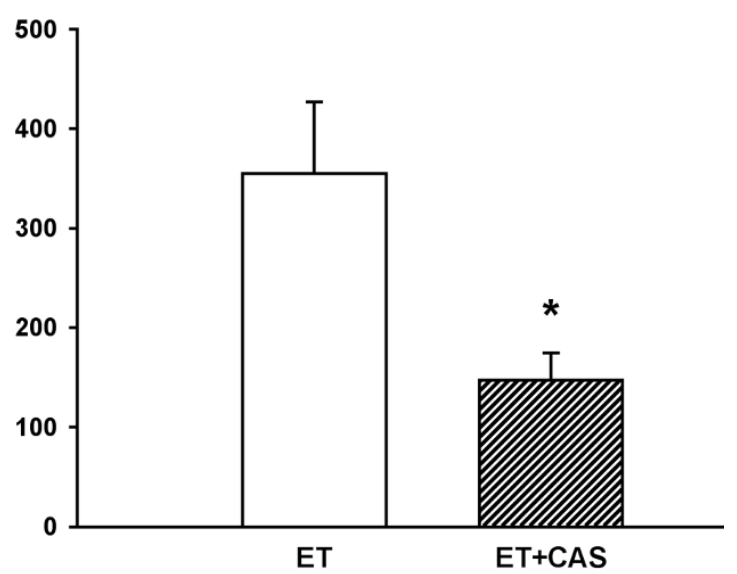

C

Fig. 1A-C. All values are given as means \pm SEM. $*: \mathrm{p}<0.05$ vs. ET.

male and female-to-male transsexuals treated with testosterone. They found that males exhibited higher ET-1 plasma levels than females and cross-gender treatment of female-to-male transsexuals with testosterone significantly increased plasma ET-1 levels. Another human study confirmed the increase of big-ET1 plasma levels in female-to-male transsexuals with testosterone treatment (van Kesteren et al. 1998). Moreover, it is known that in females suffering from polycystic ovary syndrome - a disease characterized by chronic hyperandrogenaemia- ET-1 plasma levels are elevated versus controls. Furthermore, the free androgen index in those patients is positively correlated with ET-1 plasma levels (Diamanti-Kandarakis et al. 2006).

An animal study (Ammar et al. 2004) demonstrated that 16 weeks of testosterone treatment in rabbits potentiated the vasoconstrictive response to ET-1 in isolated aortic rings. All those human and animal studies are highly suggestive that male sex hormones act as enhancers of ET-1 and its actions. However, to our knowledge our study is the first to describe a beneficial effect of androgen depletion on ET-1-induced target organ damage. Further studies are warranted to elucidate if this can be extended to other ET-1-induced injuries like ET-1 induced heart disease (Yang et al. 2004).

Taken together our study demonstrates that the detrimental renal alterations associated with ET-1 overexpression are attenuated by gonadectomy in male ET-1 transgenic mice indicating a role for male sex hormones as enhancers of ET-1-induced renal injury.

Acknowledgements: This study was partially supported by grants from the Deutsche Forschungsgemeinschaft (DFG) (PE 388/20-1 and HO 1665/5-2) and a grant from the Immundiagnostik AG, Bensheim, Germany to B. Hocher.

\section{REFERENCES}

Ammar EM, Said SA, Hassan MS. Enhanced vasoconstriction and reduced vasorelaxation induced by testosterone and nandrolone in hypercholesterolemic rabbits. Pharmacol Res. 2004; 50: 253-259.

Austyn JM, Gordon S. F4/80, a monoclonal antibody directed specifically against the mouse macrophage. Eur J Immunol. 1981; 11: 805-815.

Diamanti-Kandarakis E, Alexandraki K, Piperi C, Protogerou A, Katsikis I, Paterakis T, Lekakis J, Panidis D. Inflammatory and endothelial markers in women with polycystic ovary syndrome. Eur J Clin Invest. 2006; 36: 691-697.

Ergul A, Shoemaker K, Puett D, Tackett RL. Gender differences in the expression of endothelin receptors in human saphenous veins in vitro. J Pharmacol Exp Ther. 1998; 285: 511-517.

Haffner D, Hocher B, Muller D, Simon K, Konig K, Richter CM, Eggert B, Schwarz J, Godes M, Nissel R, Querfeld $\mathrm{U}$. Systemic cardiovascular disease in uremic rats induced by 1,25(OH)2D3. J Hypertens. 2005; 23: 1067-1075.

Hocher B, George I, Diekmann F, Zart R, Rebstock J, Schwarz A, Thone-Reineke C, Neumayer HH, Bauer C. ETA receptor blockade induces fibrosis of the clipped kidney in two-kidney-one-clip renovascular hypertensive rats. J Hypertens. 2000a; 18: 1807-1814.

Hocher B, George I, Rebstock J, Bauch A, Schwarz A, Neumayer HH, Bauer C. Endothelin system-dependent cardiac remodeling in renovascular hypertension. Hypertension. 1999; 33: 816-822.

Hocher B, Schwarz A, Fagan KA, Thone-Reineke C, El Hag K, Kusserow H, Elitok S, Bauer C, Neumayer HH, Rodman DM, Theuring F. Pulmonary fibrosis and chronic lung inflammation in ET-1 transgenic mice. Am. J. Respir. Cell Mol Biol. 2000b; 23: 19-26.

Hocher B, Thone-Reineke C, Rohmeiss P, Schmager F, Slowinski T, Burst V, Siegmund F, Quertermous T, Bauer C, Neumayer HH, Schleuning WD, Theuring F. Endothelin-1 transgenic mice develop glomerulosclerosis, interstitial fibrosis, and renal cysts but not hypertension. J Clin Invest. 1997; 99: 1380-1389. 
Polderman KH, Stehouwer CD, van Kamp GJ, Dekker GA, Verheugt FW, Gooren LJ. Influence of sex hormones on plasma endothelin levels. Ann Intern Med. 1993; 118: 429-432.

Regitz-ZagrosekV. Therapeutic implications of the genderspecific aspects of cardiovascular disease. Nat Rev Drug Discov. 2006; 5: 425-438.

Tatchum-Talom R, Martel C, Labrie C, Labrie F, Marette A. Gender differences in hemodynamic responses to endothelin-1. J Cardiovasc Pharmacol. 2000; 36: S102-S104.

van Kesteren PJ, Kooistra T, Lansink M, van Kamp GJ, Asscheman H, Gooren LJ, Emeis JJ, Vischer UM, Stehouwer CD. The effects of sex steroids on plasma levels of marker proteins of endothelial cell functioning. Thromb Haemost. 1998; 79: 1029-1033.

Yang LL, Gros R, Kabir MG, Sadi A, Gotlieb AI, Husain M, Stewart DJ. Conditional cardiac overexpression of endothelin-1 induces inflammation and dilated cardiomyopathy in mice. Circulation. 2004; 109: 255-261.
Received: November 28, 2008 / Accepted: December 3, 2008

Address for correspondence:

Prof. Dr. B. Hocher

Center for Cardiovascular Research

Department of Pharmacolcgy and Toxicology

Charité

Hessische Str. 3-4

10115 Berlin

Germany

Tel.: +49-511-8572074

E-mail: berthold.hocher@charite.de

Website:

http://www.ccr.charite.de/site/html/de/ag_hocher.html 